\title{
Critical Dialogue
}

\author{
The Liberals' Moment: The McGovern Insurgency \\ and the Identity Crisis of the Democratic Party. \\ By Bruce Miroff. Lawrence: University Press of Kansas, 2007. \\ 356p. \$29.95 cloth, \$17.95 paper. \\ doi:10.1017/S1537592710000459
}

\section{— Thomas A. Spragens, Jr., Duke University}

In his book, Bruce Miroff provides a captivating account of the ill-fated 1972 presidential campaign of George McGovern. Indeed, given Miroffs access and diligence in interviewing many of the major players, this is likely to be the definitive study of that campaign for the foreseeable future. To read it is to relive the events of a crucial episode in the career of American liberalism-and also to relive the emotions of hope, anguish, frustration, and dismay that attended them. In addition to providing such a wonderful narrative and judicious assessment of this campaign, Miroff also wants to argue that these events marked the onset of and contributed in some ways to what he calls "the identity crisis of the Democratic Party."

In retrospect, McGovern's campaign appears a Sisyphean effort doomed from the start because of a number of circumstances beyond his control. First, this country has never turned out an incumbent president in time of war. (Had George W. Bush lost Ohio in 2004, he would have scored a dubious first.) Second, as one of the campaign's principals, John Holum, said to Miroff: The campaign "really at heart was about the war" (p. 130). But the Vietnam War begun and prosecuted by the leaders of McGovern's own party, not by the opposition. (Recall in this context Robert Dole's disparaging references to "Democrat wars" in a later campaign.) Moreover, not only had Richard Nixon inherited the war McGovern wanted to end from the Democrats, but he also portrayed himself as intent upon bringing "peace with honor." Perhaps aided by his dramatic trip to China and by his resuming negotiations with North Vietnam in the summer of 1972, Nixon was able to use the powers of incumbency to trump McGovern's central issue. As Miroff says, "McGovern's 'one issue,' the American disaster in Southeast Asia about which he felt the deepest anguish, belonged in electoral terms to Nixon"; a Gallup poll showed Nixon with a $58 \%$ to $26 \%$ advantage on the question of who would do a better job in dealing with Vietnam (p. 236). Third, McGovern was saddled with heavy baggage from his indelible association with widely unpopular reference groups of the time. The early volleys of identity politics and the culture wars did not work in his favor. Fourth, McGovern was caught within a tragic tension between the moral imperative of furthering the Civil Rights revolution and important interests, fears, and values of the traditionally Democratic constituency of the white working class: Policies on busing, affirmative action, welfare, and crime impacted this group more and appeared to them differently than they did to the reformers from the suburbs who were McGovern's most energized supporters. Finally, unlike Barack Obama in 2008, McGovern came under strident attack from other candidates in his own party who savaged him as a peacenik radical, thereby setting him up perfectly as a fat target for the Republicans to finish off in the fall.

In the face of the daunting odds against him created by these burdens and obstacles, almost surely the best McGovern could have hoped for was a "noble loss" that laid the foundations for a better American future. And to some extent, he perhaps did exactly that — albeit with a significant time lag-in the sense that Obama's winning coalition in 2008, as Miroff notes in his preface to the paperback edition of this book, bore "a striking resemblance to the losing coalition of thirty-six years ago" (p. ix). At the same time, however, the McGovern campaign made a number of major mistakes that turned their loss into an electoral debacle and created a paradigmatic image of liberalism tailor-made for the Republican attack machine to use as a whipping boy for several decades.

Among the most important of these missteps that appear in The Liberal' Moment are, first, the managerial carelessness that put a chaotic face on the nominating convention and led to the devastating fiasco of the selection — and subsequent dismissal — of Thomas Eagleton as the vice presidential nominee. Second were some of the literally "half-baked" policy proposals on major issues (as one important McGovern advisor said to Miroff in an interview, "in a few cases, we were creating [McGovern's] policy as we went along" (p. 73)). The most fateful cases in point under this heading were McGovern's stated intent to cut the defense budget by nearly $40 \%$ (from $\$ 86$ billion to $\$ 55$ billion), and his proposals to create a "demogrant" that would provide every citizen an annual disbursement of around a thousand dollars and to institute an estate tax that would become confiscatory (i.e., 
approach $100 \%$ ) above $\$ 500,000$. These proposals, politically rash and - whatever their merits—substantively dramatic departures from established practice, provided rich fodder for the damaging stereotype of liberals and Democrats as "weak on defense" and as profligate fiscal wastrels determined to tax and spend indiscriminately. These stereotypes, assiduously fostered by their opponents, have cursed Democratic candidates for decades since.

Third was what Miroff calls McGovern's "blue collar problem." Despite his own genuine sympathy for the economic problems of the working class, neither the South Dakotan McGovern nor his patrician running mate were well equipped to relate and appeal to this key Democratic constituency. And their campaign workers were, if anything, worse-off, lacking both empathy and acquaintance. In Miroffs words, "Most young McGovern staffers and field organizers ... had no prior experience with workingclass life and did not know how to talk with workers [while] McGovern and his running mate, Sargent Shriver, could not compensate for this inexperience because their own feel for a blue-collar constituency was deficient" (p. 191).

Finally, McGovern allowed his anger at the folly of the war and his moral revulsion at the grievous violations of the standards for jus in bello perpetrated in Vietnam to turn him into a seemingly moralistic scold, intent more upon chastising than upon leading the American people. (I recall a colleague at the time saying to me: "I listened to his speech, and all I could think was: 'nag, nag, nag."”) As Miroff aptly observes, "McGovern's campaign speeches were instances of what scholars have indentified as the most distinctive American rhetorical genre: the jeremiad ... [a genre that] calls on a once-blessed people to face up to their fall into sin and to return to the path of redemption" (p. 129). Miroff largely excuses McGovern for his difficulties in this respect, writing that he was delivering "hard truths."

I am less charitable than Miroff here, being more inclined to see McGovern's adoption of this genre not only as politically inept but, to some extent, as inappropriate-both in general and in the specific context of the time. In the first place, the roles and tasks of prophet and President are fundamentally different and not really reconcilable. Jeremiah never ran for president (or for king of the Israelites), and would never have been foolish enough to think he could do so while remaining true to his views and his mission. McGovern needed to decide whether he wanted to do his public service by providing prophetic critique or by becoming president-and not to think he could do both. (In like manner, Jimmy Carter-another preachertype Democrat - wound up not only looking risible but also sealing his fate as a one-term president by giving his "crisis of confidence" speech that purported to plumb the flawed condition of his countrymen's souls.)

Given the specific facts of the matter that gave rise to McGovern's prophetic insistence that Americans had to "change those things in our character which turned us astray," such a stance of moral condemnation moreover, was not entirely appropriate and simultaneously compounded the impression that he was an elitist derogator of average Americans. Hearing themselves so denounced for their fall into sin, consider the likely response of, say, a blue collar worker with a child in the military: "Let me get this straight, George. A few short years ago a Democratic President told us not to ask what our country could do for us but what we could do for our country and said that we as a people would have to be willing to pay any price and bear any burden in defense of freedom. So we stepped up and were willing to see our sons shipped off to war so to sacrifice for our country. And now you want to berate us as sinners and tell us we need to change our character!?" Even after the fact, McGovern seemed clueless about the problematic element of sanctimony in such circumstances, concluding "that he had erred in assuming that he could rely on the fundamental decency of the American people" (p. 139).

The centerpiece of Miroffs attempt to discern the "meaning" and "legacy" of the McGovern campaign is his claim that Democrats suffer from an "identity crisis." Here, the argument inevitably becomes more contestable. The essence of this crisis, in the author's view, is a deep tension "between their hearts and their heads," between "idealistic convictions" about peace and equality on the one hand and "practical calculations" about how to win elections on the other "in a country whose majority evidently does not share such convictions" (p. 3). The resolution of this crisis, Miroff writes, demands a "therapeutic process through which Democrats can regain their confidence that they know who they are [and] to recover what they believe," their "core convictions" about "economic justice, social equality, and a more multilateral and multifaceted strategy for national security." Miroff hopes in this context for the appearance of a new version of Franklin Roosevelt, "who understood better than any of his Democratic successors how to blend the liberal vision of political transformation into the American political tradition." To do that, Miroff suggests, requires "reshaping and refining" of the "core liberal convictions" to take into account the beliefs and interests of "constituencies that have turned away from the party," although he demurs when it comes to saying what such a "full-blown alternative" might look like (pp. 303-305).

There seem to me, however, to be several difficulties with this rendering of the task facing contemporary liberalism. I mention here only in passing that Miroffs intimation that we live "in a country whose majority evidently does not share [liberals'] idealistic convictions about equality and peace" (p. 3) seems unduly pessimistic and also incompatible with his apparent conviction that some refined version of liberal ideals can be made politically palatable without dissembling. More crucial issues 
surround the construction of the different poles of the identity crisis itself. On the "heart" side, it seems to me that one could raise serious doubts about whether there really are the kinds of clear and unequivocal "core liberal convictions" that the author takes for granted. Economic justice, social equality, and international peace are all nice phrases, but what exactly do these phrases mean in terms of concrete goals and policies in today's America? And when such specification is demanded-as it must be before laws can be crafted or policies devised-are American liberals so clear or unanimous in their core convictions as Miroff supposes? I actually doubt it, seeing a good bit of indeterminacy and disagreement herereflected in academic disputations among Rawlsian liberals, civic liberals, neorepublicans, and agonistic democrats, for example. And on the other pole of the alleged identity crisis, how fair or accurate is Miroff's construction of Democratic centrists or neoliberals as merely backsliders whose ideas are marked by "pervasive ideological confusion" (p. xiii, vis-à-vis Bill Clinton) and whose motives are basically timorousness in pursuit of electoral success. Miroff quotes Sandy Berger as construing the move from his early McGovernite initiation into politics to "actual governing" in the Clinton administration as being a "process of political maturation" (p. 296). This characterization is clearly at odds with Miroffs own depiction of Clinton's "Third Way" as ideologically confused opportunism, but he never confronts and engages Berger's alternative view of things. It would have been very helpful here to know exactly why the considered views of selfconstrued "matured" veterans of the McGovern campaign, including Berger, Clinton, and Gary Hart, do not warrant more serious consideration, even if only in refutation. Absent such a critique it becomes hard to know why it is Miroffs version of liberal core convictions that are the ones whose reshaping and refining will provide the basis for resolving the Democrats' identity crisis with a new and more compelling public philosophy.

It clearly is not fair or reasonable to expect Miroff to get us very far down the road toward a new liberal identity in a brief epilogue to this wonderful study of the watershed election of 1972. But more serious discussion of principles, policies, and strategies will be needed before contemporary liberals can decide whether his construction of their identity crisis represents a useful guide to greater electoral success for them and to a better future for the country. My own sense is that such a favorable outcome will require American liberals to take a more probing look in the mirror, to modify rather than merely refine some of the core convictions bequeathed to them from the sixties, and to incorporate their distributive concerns into a broader and more compelling vision of an inclusive democratic community capable of providing the personal freedoms and the sustaining institutions needed for all its people to lead flourishing lives.
Response to Thomas A. Spragens's review of The Liberals' Moment: The McGovern Insurgency and the Identity Crisis of the Democratic Party

doi:10.1017/S1537592710000460

- Bruce Miroff

Before I respond to Thomas Spragens's commentary on my book, I want to thank him for the thoughtful and gracious tenor of his review. Despite our differences about the legacy of the McGovern campaign of 1972, we agree that the campaign was a watershed in the development of contemporary liberalism and that it deserves reexamination by those who seek to address liberalism's future in American politics.

Spragens devotes considerable space in his review to a critique of George McGovern for arguing during the campaign that Americans had gone morally astray in their conduct of the war in Vietnam. I agree with him that McGovern's passionate moral condemnation of the war was impolitic for a general election campaign-although without such rhetoric, a junior senator from South Dakota would never have attracted the following that carried him to the Democratic presidential nomination in 1972. Further, I agree that McGovern's language about the war should have been more sensitive toward the sacrifices of the working class, whose sons (white and black) had disproportionately done the fighting and dying in Vietnam. Where I part company with Spragens is on the sharp distinction he draws between prophets and presidents in the uses of the jeremiad. As I briefly note in my book, Abraham Lincoln and Franklin Roosevelt employed the tropes of the jeremiad and asked Americans to come to terms with moral failings. To deride this type of discourse as nagging and rule it out of bounds for political figures is to restrict the room for moral leadership in American public life.

Spragens's fundamental disagreement is with the concluding section of The Liberals' Moment, which takes up what I call "the identity crisis of the Democratic Party." In the last part of the book, I argue that a legacy of the McGovern campaign is that while the base of the Democratic Party has become more thoroughly liberal since the 1960s with the departure of conservative southerners and Cold War neocons, Democratic leaders, fearful of replaying the electoral disaster of 1972 , have positioned the party in the center for presidential elections. Spragens takes issue with my depiction of the Democratic base, specifically my claim that contemporary American liberals share core convictions about economic justice, social equality, and international peace; these convictions, he suggests, are neither clear nor unanimous on the Left. That there is ambiguity and argument about Democratic convictions I readily acknowledge. Nonetheless, there is ample evidence from opinion surveys and congressional voting patterns supporting my perspective on what Democratic liberals believe. 